\title{
Religious Responses to Social Distancing Revealed through Memes during the COVID-19 Pandemic
}

\author{
Heidi A. Campbell ${ }^{1, *}$ and Zachary Sheldon ${ }^{2}$ (D) \\ 1 Department of Communication, Texas A\&M University, MS 4234, Bolton Hall, College Station, TX 77843, USA \\ 2 Department of Film and Digital Media, Baylor University, One Bear Place \#97321, Waco, TX 76798, USA; \\ zachary_sheldon@baylor.edu \\ * Correspondence: heidic@tamu.edu
}

Citation: Campbell, Heidi A., and Zachary Sheldon. 2021. Religious Responses to Social Distancing Revealed through Memes during the COVID-19 Pandemic. Religions 12: 787. https://doi.org/10.3390/ rel12090787

Academic Editor: Alphia

Possamai-Inesedy

Received: 6 August 2021

Accepted: 13 September 2021

Published: 20 September 2021

Publisher's Note: MDPI stays neutral with regard to jurisdictional claims in published maps and institutional affiliations.

Copyright: (c) 2021 by the authors. Licensee MDPI, Basel, Switzerland. This article is an open access article distributed under the terms and conditions of the Creative Commons Attribution (CC BY) license (https:// creativecommons.org/licenses/by/ $4.0 /)$.

\begin{abstract}
This article examines the emotive narratives surrounding the "new normal" of social distancing practices during the first six months of the COVID-19 pandemic, as revealed by religionfocused Internet memes. In March 2020, many people were introduced to the concept of "social distancing" for the first time via news reports and media coverage of the spreading COVID-19 pandemic which led to the first lockdown. As the year progressed, social distancing discourse was combined with discussion of the practices of masking and quarantining, all of which became part of many countries' normal routines as a public health management strategy. Over time, social distancing has become a widely used public health strategy impacting many social groups, including religious adherents and their places of worship. Memes became a discursive space where practices of social distancing and religious attitudes towards these practices were expressed and debated. By examining memes centered on American Christianity, this study reveals that memetic narratives in the early months of the pandemic indicate a positive framing of behaviors intended to help reduce the spread of COVID-19, and a negative framing of the attitudes of religious individuals and organizations who seem to privilege the cultural practices of their belief over the core values of the Christian faith.
\end{abstract}

Keywords: Christianity; COVID-19; internet; memes; pandemic; social distancing; Zoom

In the early months of the global COVID-19 pandemic, internet memes shared on social media became a critical location of symbolic discourse surrounding the virus and public health practices such as masking and social distancing, which were intended to reduce the spread of the virus. Just as the virus spread rapidly through viral means across the globe, so did popular internet memes, revealing common opinions and interpretations of these "new norm" practice and the responses from various groups to them. Over the past year, internet memes and meme characters have been used to showcase and promote common and even conflicting opinions about these now everyday pandemic safety-social practices.

This study focuses on religion-focused, imaged-based internet memes, a unique online communication medium that uses digital images and a range of recognizable stock characters which are combined with different humorous texts to present succinct visualtextual messages. In this study, we define internet memes as a digital artifact that represent an "idea, belief or behavior that is spread through a given culture or social system through social or information sharing" (Bellar et al. 2013, p. 4). They are typically comprised of a digital photo or drawing, accompanied by a caption. Memes are humorous and even ironic, intended to provoke both laughter and critical thought. Since the early days of the pandemic, memes have been a popular way for people to depict and explain in playful or serious ways the importance of social distancing practices in a variety of social contexts. As the pandemic has continued, memes are frequently recycled, remixed, and recreated to capture public debates about pandemic social practices from the perspectives of many different groups. This includes a notable collection of memes commenting on religious groups' and individuals' responses to the pandemic. 
Through careful reflection, we noted that these internet memes became public storytellers of the prominent religious responses towards pandemic practices and constraints. Internet memes were not only used as a humorous tool to cope with stress and anxiety brought on by social distancing but also to provide a running commentary of the religiously motivated responses or justifications for certain practices emerging in public discourse about the global pandemic. This has led to our guiding research question:

What are the primary stories that internet memes tell about religion, in light of social distancing practices during the COVID-19 pandemic?

This research focuses specifically on the religious interpretations of the pandemic practices of social distancing and explores the way people attached a variety of social, cultural, and even religious meanings to social distancing and pandemic-focused memes in their attempts to articulate their understanding of these practices to others. The artifacts of this study focus on the context of American Christianity. Our findings indicate two divergent narratives surrounding such memes relating to social distancing. First, Christian-focused memetic narratives positively frame public health practices intended to reduce the spread of the virus. Second, these memes also tended to criticize the attitudes and actions of Christians and Christian churches towards social distancing practices. This means while the Christian-focused memes in this study primarily affirmed following social distancing protocols, they also assumed that these practices were being ignored by many or most sectors of the Christian church. The result is that memes became tools of critique for the perceived privilege of American Christianity, suggesting that Christian groups' responses to the pandemic were primarily driven by freedoms of expression and individualism rather than moral or theological values of care for the other.

\section{Internet Memes as Storytellers}

Internet memes have become a growing area of research within Media Studies, helping scholars explore the nuances of cultural and political critique within digital culture (i.e., Milner 2018; Wiggins 2019). Internet memes are popular because they are easily created through online meme generators and can be shared virally through a variety of social media platforms such as Facebook, Twitter, and Instagram. The formulaic nature of image-based internet memes also makes them easy to decode, as they follow standard formats that can be easily interpreted, mimicked, or adapted. This process of remixing is central to meme culture, meaning the flexibility of memes encourages people to adapt meme characters and their slogans to new events and personal beliefs, thereby creating a dynamic process of storytelling online. With the addition of personalized touches, memes exist with awareness of one another and take on the beliefs and perceptions of their creators. Simply put, internet memes are constructed using images, typically from popular culture, and supplemented with text.

Shifman (2013), one of the key developers of the study in internet memes, says memes also play an important role in online culture by empowering people with a unique form of "political participation". By this she means that internet memes allow individuals to voice their convictions publicly in a new and unique way. Internet memes can offer a non-traditional space in which public debate can be conducted. By being both flexible and formulaic, they offer a creative visual-textual language where people can resist social norms, demonstrate public support, or critique political agendas. In other words, memes offer a space for people to present or assert their opinions and influence public debate on current events in ways that are often elusive and go unrecognized because they are disguised within humor. As such, memes are a form of digital media that offers an "appealing and convenient way to stimulate participatory activity" outside of traditional public forums (p. 120). This, we suggest, is what is happening in the case of pandemic memes, as they became tools of creative expression to push forward particular agendas and arguments about the pandemic in the public sphere of the Internet. 


\section{Studying Religion and Internet Memes}

Over the past seven years, serious attention has been given to the study of religious memes and their ability to communicate common or popular beliefs about religious traditions and groups in contemporary society. Studies have looked at religious memes by examining the ways that religion is framed and filtered through memes (i.e., Aguilar et al. 2017), the religious-political narratives promoted by memes (Duerringer 2016), and how memes represent different religious groups, including Mormons (Borrough and Feller 2015), Muslims, and Hindus (Campbell et al. 2018b). Based on these studies, memes draw on different understandings of religion. For example, studies define religion in terms of official institutional structures (Borrough and Feller 2015), "lived" forms of religion that highlight everyday personalized religious practices of adherents (Aguilar et al. 2017), or "civil religion", which emphasizes the religious narratives and symbolism embedded in politics (Campbell et al. 2018a).

As noted above, much of the research exploring the messages that internet memes communicate about religion has focused on how memes can be used to create distinctive imaging about particular religious individuals (Dewi 2018), their practices (Yadlin-Segal 2015), or related institutions (Church and Feller 2020). Some work has also explored how memes offer scholars unique, highly visible cultural artifacts that depict common interpretations held by the public about religion and its impulses (i.e., Singler 2020). Within both perspectives, studies of Christian memes have primarily suggested that they present Christianity as a lived religious practice, where such memes reveal how people live out or understand the Christian faith to be enacted on a personal level in everyday life. Within this tendency, scholars have noted a limited range of ways in which religion is generally presented through memes. This includes memes playing with, promoting, questioning, critiquing, or mocking religion (Aguilar et al. 2017).

This study specifically focuses on how internet memes produced during the pandemic tell stories about pandemic social practices from a religious perspective, especially as it relates to American Christianity. We seek to investigate the ways that memes with religious themes promote and/or critique certain aspects of socially distanced focused memes by employing religious language and imagery to make sense of pandemic social practices in relation to religion and religious rituals.

\section{Studying Religion, the Pandemic, and Social Distancing}

Over the past year, scholars' attention has been drawn to the role that memes and meme cycles play in visualizing public tension and responses to the COVID-19 pandemic. This includes how memes have stereotyped particular populations (i.e., Al-Rawi et al. 2021), how memes can contribute to the circulation of bias or misinformation (i.e., Sebba-Elran 2021), and the ways that memes can reflect or help create rhetorical strategies that reinforce and shape public perceptions of the coronavirus (i.e., Pulos 2021). Yet little attention has been given to the stories that religion-focused internet memes tell about religious groups and the pandemic except to simply name this phenomenon (Campbell 2020c; Merkert 2021) or highlight the tendency of pandemic memes to promote religious bias and negative framings (Rajan and Venkatraman 2021), a tendency already noted in previous research (Campbell et al. 2018a, 2018b).

Although all areas of modern life were disrupted by the onset of the COVID-19 pandemic, the pandemic's impact on the life and practices of religious communities have been of particular interest to journalists and scholars alike. Community and communal gatherings are essential components of many religions and religious traditions, such that the requirements for distancing and shelter-in-place orders disrupted many standard religious rituals, from weekly services and gatherings to religious holidays such as Passover and Easter. As such, churches and religious individuals had to respond to these challenges and many disruptions to their traditions in 2020. Many churches were caught off guard by the technological necessities required to move services online (Yuko 2020), even as many people turned or returned to faith as a way of coping with the anxieties of the global situation 
(Yee 2020). Restrictions on in-person gatherings immediately raised questions in the United States about religious freedom and the regulatory capacity of government over religious institutions (Schor 2020). Many religious adherents expressed doubts about the ability of religious practices to ever return to a pre-pandemic normal (Gjelten 2020). Despite these complications, the Pew Research Center reported that across 2020, a significant portion of Americans found that the pandemic had increased the strength of their personal religious convictions (Pew Research Center 2021).

Scholars and clergy have also weighed in with insights into the ways that religion has been impacted by the pandemic, how religious institutions have, can, or should respond to the pandemic, and how religious belief has made a difference in such challenging times (Campbell 2020a, 2020b, 2021).

In studying religion and the pandemic, of particular note has been ways that the religious and the political have become challengingly intertwined in the United States context over 2020, especially in regard to the information and policies related to COVID-19. As previously mentioned, controversy quickly erupted when government shutdowns and stay-at-home orders impacted religious gatherings, raising questions about religious freedom. Over the course of the pandemic, many churches adhered to local, state, and federal regulations regarding in-person meetings, while others blatantly defied such orders on theological grounds (Molina 2020). Even as the COVID-19 death toll in the United States surpassed 600,000, many religious individuals were still reluctant to adopt public health measures such as vaccinations or masking that could slow or prevent the spread of the virus, leading some to blame some of the country's continued woes in dealing with the virus on religious individuals, especially evangelical Christians (Lovett 2021). What this points to is a division amongst even religious individuals and institutions over the appropriate religious response to COVID-19 and public health practices-such as masking and social distancing - which were instituted by government entities to combat the spread of the virus. Because government mandates controversially restricted in-person gatherings, which had a direct impact on traditions of religious practice, other government recommendations (such as mask wearing) were at times controversial by association, raising questions about government control and whether religious individuals needed to obey such orders. As such, public health practices that were arguably straightforward from a medical perspective became far less straightforward when they were instituted in religious settings. Responses to COVID-19 were never universal nor uncomplicated, but the peculiarities of religious freedom and convictions regarding religious practices in the United States especially created often differing convictions for how religion and religious practice could or should flourish under pandemic conditions.

Thus, both studying religion in the pandemic and specific practices such as social distancing involves navigating the sometimes competing interests of faith, politics, medicine, and the individual experience. Social media has been one critical tool for individuals to voice their opinions, see, and hear the opinions of others, and collectively make sense of world and local circumstances. Memes are one critical way that individuals have done this work, using humor and the micronarratives contained in memes to tell stories about their own experiences and how they have made sense of events around them. As such, studying memes is a useful opportunity to analyze the narratives and ways of meaning making that surround new social practices in the COVID-19 pandemic at large.

\section{Methodology}

This study's aim is to identify the religious narratives that internet memes communicate about the social practice of social distancing, which became a norm for most around the world during the pandemic. Highlighting the dominant stories that these religious pandemic memes showcase about the pandemic's social practices aids in unpacking the key discursive narratives about the ways that individuals and groups in American Christianity made sense of how social distancing impacted standard religious practices and expressions of individual and communal faith. 


\subsection{Initial Sampling of Social Distancing Memes}

Memes were collected primarily through a specific Facebook Group called "Holy Pandemic! Encouragement \& Memes" (see: http://www.facebook.com/groups/220412 19012000 / , accessed on 6 September 2021). The group was created in March of 2020 by Dr. Heidi A. Campbell to share pandemic-focused memes, especially those with religious themes. The group initially served as a way for her to cope with the stress and anxiety created by the uncertainty of the coronavirus while she was temporarily quarantined in Germany. Starting with an original invitation to 80 Facebook friends, the group grew in one year to over 2200 members from around the world. Together, this group has shared over 7000 memes with each other on a wide range of topics related to the pandemic.

This article specifically centers on the memes that tell stories about the general range of responses of religious individuals and groups towards social distancing practices during the first four months of the pandemic (mid-March to late-June). During this period, approximately 1176 posts were made to the Holy Pandemic! Facebook group, which is an average of 14 memes a day being posted by various members. Members of the research team went through these posts and identified 223 of these memes as referencing the act of social distancing. This represents $19 \%$ of all the memes posted to the Facebook group during the first three months of the pandemic. Analysis of this set of social distancing memes were presented in an eBook report (Campbell 2020c) that was part of a larger Digital Humanities project visualizing meme narratives on social distancing. For that project and this study, social distancing was defined as the practice of maintaining a safe or appropriate physical distance from other people, or other measures taken to reduce close physical contact, especially to slow the spread of COVID-19. The included memes spotlight various aspects of maintaining a safe distance between others in order prevent the spread of the coronavirus either through images used, references made in meme texts, or both. It was noted that religious themes, in general, were highly visible in many of the memes originally collected (Campbell 2020c). This study seeks to identify and unpack in detail the stories that such memes presented, and the implication of these narratives for how religion and religious groups are represented through memes during the pandemic.

\subsection{Meme Categorization and Analysis}

While the Facebook group from which the meme samples were drawn began in midMarch, it was not until mid-May that this growing collection was viewed as a potential site of research due to the diverse and large meme collection being created. At this point, Campbell approached the group to ask permission to draw memes from the group to create a research collection. After permission was received, memes were collected into a research database which is described in greater detail below. Only meme images were collected, no other personal identifiers or quotes were recorded, so memes could be studied as narrative objects rather than as being interpreted as an individual's opinions regarding pandemic issues.

The research team began to collect snapshots of each meme that was focused on social distancing from the group using an Excel database. Other information was also collected as the sample grew, identifying pandemic-related themes reflected in each meme and common stock characters or meme macros used. This information, as well as copies of all meme images, were later transferred to an interactive database app specifically designed for a project focused on studying social-distancing-focused memes. The app database enabled the research team to tag, sort, and run simple correlation reports on dominant topics and narratives highlighted in the initial meme sample.

In the database app, memes were further categorized on the basis of common meme characters or icons used, supportive or critical narratives, and common symbols and argumentation references used. In this initial Digital Humanities focused study of social distancing memes, three common themes were identified: (1) how social distancing created a host of new, related behaviors; (2) how humor and memes especially were a key coping mechanism to stress caused by social distancing; and, finally, (3) how religious groups and 
institutions in particular shifted their practices in response to the new behaviors required by the principle of social distancing. Further details of findings were published in an eBook (Campbell 2020c). It was from this analysis that religious response to social distancing was identified as a prominent category in need of further examination.

\subsection{Finalizing Sample of Religious Social Distancing Memes}

This process also helped identify the core themes and narratives about religion that emerged from this collection. The collection of social distancing memes was further sorted to include only those which made reference to religious themes, such as highlighting how religious individuals or groups specifically perceived social distancing practices or showcased how religious events or rituals might need to be altered to be in line with safe social distancing regulations. The final sample of social distancing memes with a focus on religious themes resulted in 75 of the 223 memes, or $34 \%$ of the total sample of social distancing memes.

The memes dealing with religious themes primarily referenced Christianity. This reason determines that the majority of the members of the Facebook Group came from America or British origins, where Christianity is the dominant religion in both regions. These memes covered a variety of themes that will be discussed below. Memes were also categorized in relation to the religious frames used in these memes, as identified by Aguilar et al. (2017). Their study identified the most common ways that religion is framed in popular memes. This includes categories such as depicting religion in playful terms, promoting religious belief and practices, questioning religion, mocking religion, or suggesting that religion is irrational.

\section{Stories Told about Religion and the Pandemic through Memes}

Four prominent themes or stories emerged through the analysis of religion-focused social distancing memes collected, each having similar level of visibility within the final sample. These included memes highlighting: (1) new ways of "doing" religious rituals amid the COVID-19 pandemic $(\mathrm{N}=15)$, (2) the realities of Zoom/livestreamed church ( $\mathrm{N}=15)$, (3) the realities of Zoom/livestreamed church $(\mathrm{N}=14)$, and (4) religious characters helping define acceptable COVID-19 health and safety protocols $(\mathrm{N}=13)$. Although some memes could easily be grouped into more than one these themes, each meme was associated with the story it most directly highlighted. These stories are described in more detail below.

\subsection{Requiring New Ways of "Doing" Traditional Religious Rituals Amidst COVID-19}

Memes in this first category (Figure 1) focused on creative depictions of social distancing practices that forced modifications of traditional religious practices. This is exemplified in 15 memes, 10 of which focus on the religious sacrament of baptism, and hypothetical and playful ways it would have to be modified due to social distancing restrictions. This is clearly seen in the meme depicting a "Social Distancing Baptistry" that shows a photograph of a carnival dunking booth that playfully suggests that dunk tanks could now be used as a socially distanced form of baptism by immersion. Another example of this theme includes an image of a priest aiming a water gun at an infant, offering an alternative to baptism by sprinkling or immersion. In both cases, humor is used to reinforce the oddities of social distancing as a practice but also to subtly affirm that religious beliefs and practices may still be able to continue despite world circumstances. These practices may take modified forms that are not as extreme as those depicted in the memes but are nonetheless able to be perpetuated. Humorously worth noting, too, is that baptism operated as a sacrament of consensus in this data set: though different Christian denominations affirm different types and styles of baptism, all multiple types were represented in these memes and comedically modified to affirm social distancing practices. 


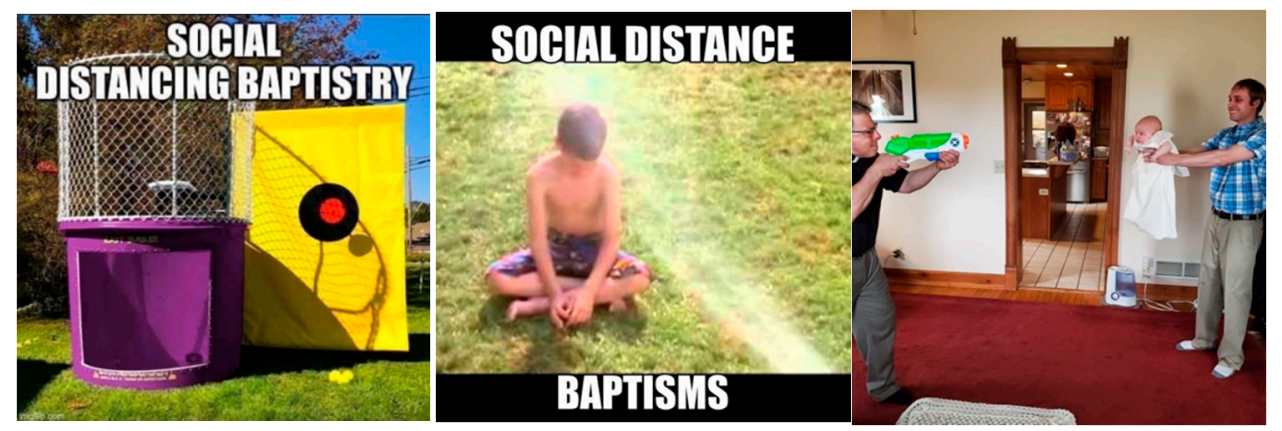

Figure 1. Examples of memes that present how the ritual of baptism has been playfully reimagined due to social distancing.

\subsection{Zoom/Livestreamed Church Becomes the Norm and Creates Challenges}

As seen in Figure 2, some of the most visible and consistent alteration to religious practice across the pandemic was the lack of in-person services due to limitations on gathering sizes especially in indoor spaces. "Zoom church" was quickly instituted as churches and religious communities shifted online, making use of video chat and streaming software such as Zoom. Of interest to scholars of media is the way that the transition to "Zoom church" presented challenges to the form of worship services. Scholars have cataloged the transformation of church services across new media such as television (Schultze 1991) and the internet (Hutchings 2013), finding that services had to become more entertaining, and churches had to work harder at fostering connection and community in order to attract and maintain members. "Zoom church", then, offers a new challenge as a further transformation of church services away from even the televised era. Fifteen memes in our data set explicitly referenced practices of watching church online from home and described or critiqued such practices. One meme is a web comic meme that depicts the various stages that someone goes through in livestreaming a church service via their laptop. The figure in the comic sits through the "opening credits" or announcements, there is an "interval" where her cat rests atop her computer, she later experiences "the realization that this was last week's episode" as the service progresses, and the comic ends with the computer screen recommending other churches and services for her to watch. In both its form and references, this meme compares the ways that watching church online via something such as a laptop can be strangely similar to watching a movie or TV show on one's computer. Further references to the strange realities of watching church from home can be found in another meme picturing a young couple laughing together; the woman in the picture asks where they should go to church, and the man responds with, "I don't know! The living room or the dining room? You choose!" This reinforces the notion that social distancing and gathering restrictions eliminated many of the aspects of choice regarding choosing or attending church services. Instead, the only choices that many people had were where in their own home they accessed or watched a church service online.

\subsection{Religious Belief Can Be Used to Promote COVID-19 Safety Measures}

As the scope and scale of the pandemic became apparent, public health messages emphasized the need to implement various social distancing practices to keep people safe. Many advertisements worked to carefully find the right motivation to compel viewers or hearers to adopt such behaviors even as COVID-19, its virality, and the correct strategies for combatting its spread remained largely unknown. Memes played a role in showcasing the motivations for implementing COVID-19 safety measures and in attempting to deliberately motivate people to do so. Religious memes centered on how the moral component of religion supports and can motivate the adoption of social distancing practices (Figure 3). Fourteen memes in our sample exemplified this narrative, including several that depicted various church marquee's supporting social distancing, characterizing such behavior as "an act of love", for instance. Another meme features a picture of Jesus knocking on a door (a reference to Revelation 3:20, where Jesus says, "Behold, I stand at the door and 
knock", [ESV]) telling "Debbie" on the other side of the door to "stop telling people that your health is in my hands and start washing your hands". Though Christian theology teaches the omnipotence of God and encourages the understanding that people's lives and health may be entrusted to God, here, Jesus advocates for religious faith to motivate good public health practices such as washing one's hands or social distancing. These memes seek to tie religious belief to concrete action and see social distancing as an expression of religious love.

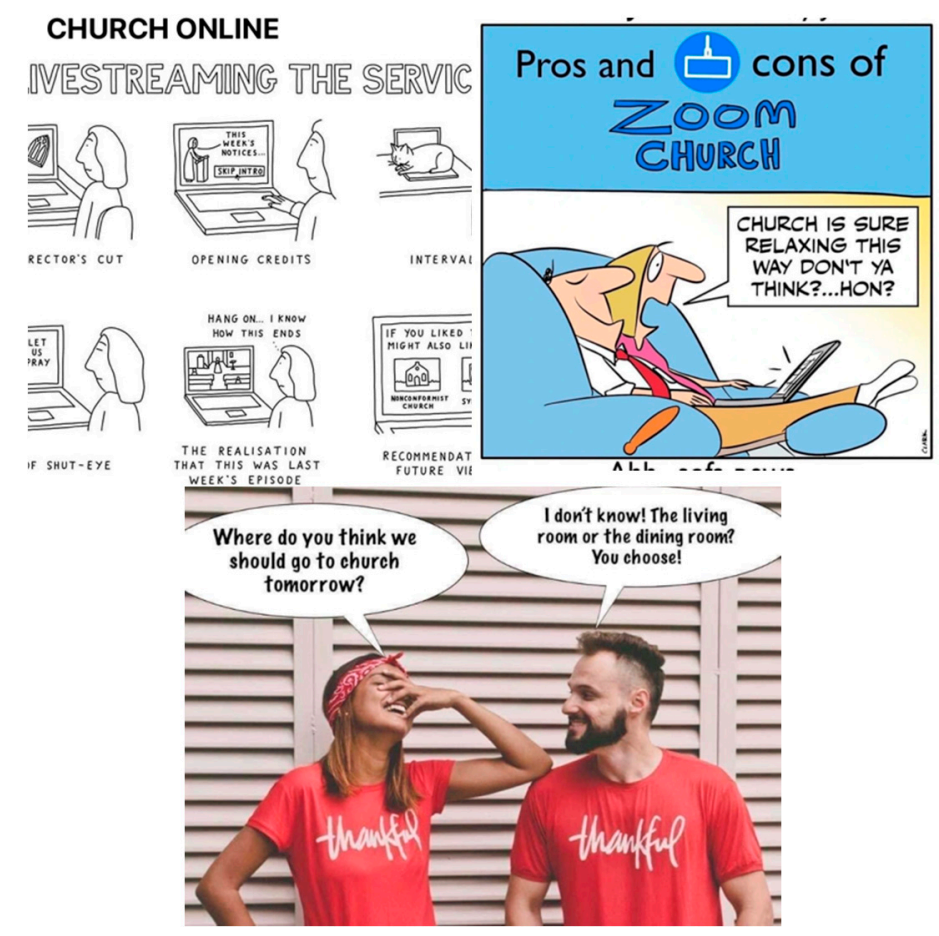

Figure 2. Examples of memes that suggest what church online is like during the pandemic, and people's reactions to these experiences.

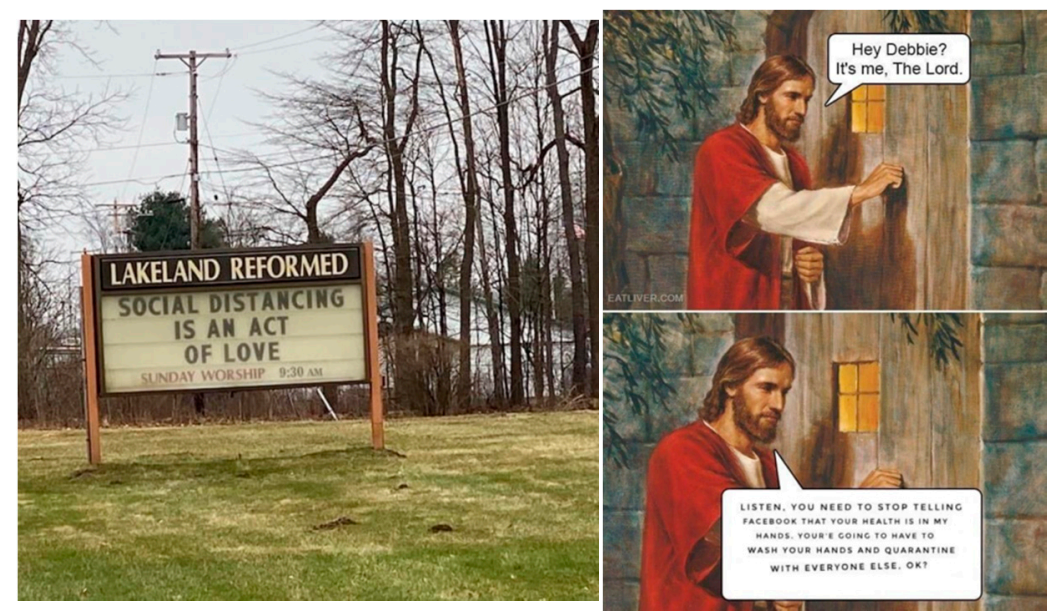

Figure 3. Examples of church sign memes and Jesus memes emphasising that social distancing should be seen as a Christian act.

\subsection{Religious Characters Help Define Acceptable COVID-19 Health and Safety Protocols}

Thirteen memes in our sample playfully engaged with well-known biblical stories and figures to describe social distancing protocols or to joke about their implementation and how it might have changed such stories (Figure 4). One meme references Zacchaeus, a short tax collector who wanted to see Jesus so badly that he climbed into a tree to get above 
a crowd in order to do so, a story taken from Luke 19: 1-10. The meme sees Zacchaeus up in the tree as being socially distant from the crowd, and so playfully calls him "social distancing champion" as if to say that he was socially distancing before social distancing was a norm. Other memes played on the fact that the pandemic emerged and lockdown orders came not very long before the Easter season. Images depicting Christ rising from the dead and leaving his tomb were juxtaposed with messaging that people are supposed to stay inside and distanced-in one meme, the ostensible voice of God tells Jesus, "Not this year, son, ya gotta stay in", while another meme features a Roman soldier telling Jesus to go back inside his tomb due to "quarantine regulations". These memes take well-known religious figures and illustrations and subtly shift them to make light of the new reality of social distancing protocols and to helpfully describe the acceptability of such protocols.

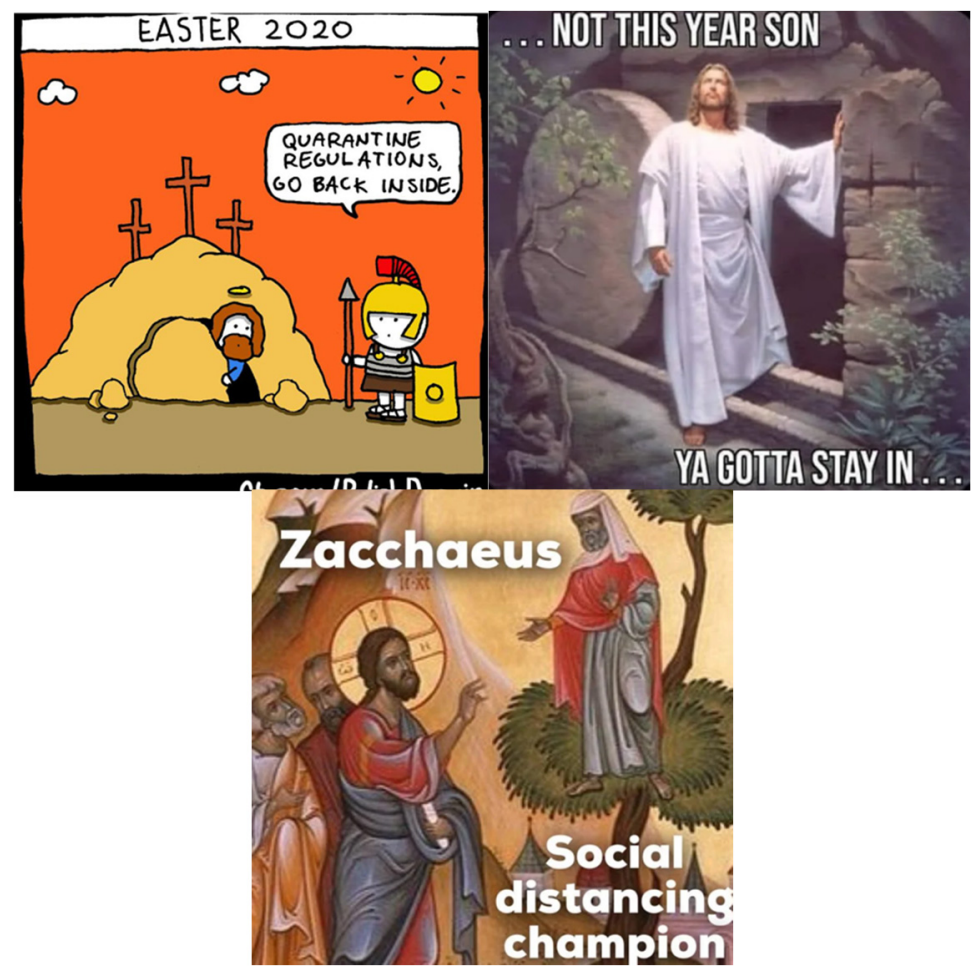

Figure 4. Examples of memes that depict Jesus as supportive of social distancing behaviors.

\section{Discussion: Representations of Religion in Pandemic Social Distancing Memes}

Overall, the stories highlighted by memes collected in this study featured many positive framings of religion, suggesting many Christian groups were engaged in or supportive of social distancing. A majority of the memes collected showcased a general belief that there is or should be a consonance between Christianity and the affirmation of social distancing practices, as both share an ethic of care for others. Yet there was also a prominence of memes that suggested some Churches and many Christians frequently viewed practices of social distancing and masking with suspicion. Some aspects of "new normal" social practices were both satirized and critiqued within memes, and many such memes framed social distancing in terms of advocacy, exhorting religious groups to adhere to these practices.

Thus, within these religious narratives about social distancing as represented through these memes was a mixed message; religion in general, and Christianity more specifically, was both supportive and resistant to social distancing. Stories told by memes about religion during the pandemic often dealt with highly practical elements of social distancing practices and their manifestations in new behaviors or activities. Memes often depicting Christian religious practices or beliefs, as manifest during the pandemic, in such a way that they revealed an assumption of religious people would be critical of social distancing and 
therefore needed to be coaxed or exhorted to follow these pandemic safety precautions. As a result, many memes used religious beliefs and characters as a bridge to motivate individuals to adopt new behaviors. Taking a broader perspective, we see both a positive and negative view of religion within these memes. In other words, memes framed a religious outlook as both supportive of and yet notably resistant to social distancing behaviors. In this section, we discuss four themes: two showing how religion could serve as a motivation for people towards social distancing practices and two highlighting assumptions that religious groups were inherently averse to these actions. We begin by exploring how memes framed religion in a positive light such as (a) churches encouraging COVID-19 protocols and (b) social distancing as a facilitator of creative religious innovations.

\subsection{Positive Narratives about Religion}

\subsubsection{Churches as Encouraging COVID-19 Protocols}

The most prominent positive framing of religion within the social distancing memes studied suggested religious groups should be encouraging the upholding of social distancing COVID-19 protocols (Figure 5). Many memes exhorted churches and other houses of worship to publicly affirm health and safety edicts and practices, and that affirming social distancing was more than a choice but a responsibility for religious groups. For instance, one meme featured an image of an empty church alongside a depiction of Jesus' empty tomb with the text, "Be empty on Easter". This meme tells a story that acknowledges the realities of a prominently altered church ritual-the church gathering itself-while tying that altered reality to the sacrificial story of Jesus and the transcendence of His actions. The meme effectively argues that just as Scripture teaches that Jesus transcended the limitations of death, Christians can transcend the limitations of COVID-19 through right, Christ-like action. Though the theological equivalence of an empty church and the empty tomb is suspect, the evocation of the tomb in the imagery of the empty church positively frames the sacrifice of Christians not worshipping in person as a Christ-like thing to do. Likewise, one meme aimed at religious Jewish shared an explicit "Blessing for the Mitzvah of Putting on a Mask" that encouraged prayer for the action of putting a mask on, recognizing such an activity as obedience to Hebrew Scriptural commands to protect life.

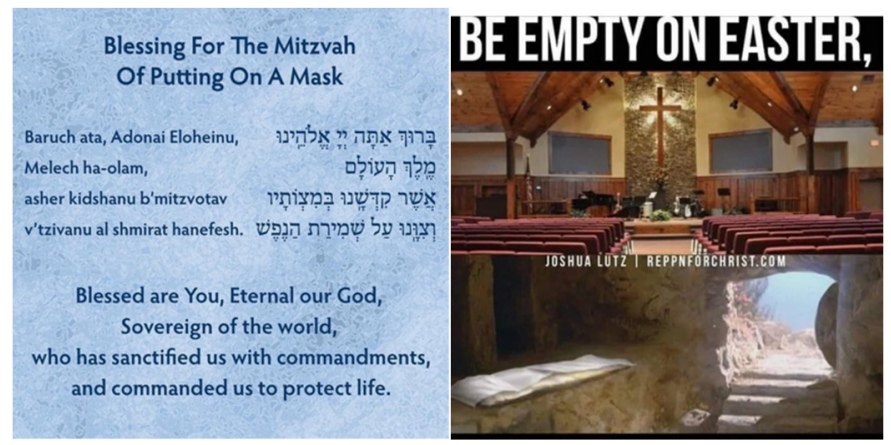

Figure 5. Examples of memes that depict religious communities as advocates of social distancing practices.

\subsubsection{Social Distancing Can Facilitate Creative Religious Innovation}

Another positive narrative promoted by these memes was that rather than social distancing being seen as a limitation to religious groups and their practices, it could be seen as a facilitator of creative innovations. Those same memes that told stories about altered rituals and the realities of church online effectively acknowledge the ways that religions and religious practitioners had to innovate or make do in order to practice their faith or were simply able to see their faith in a new light as a result of such shifts. Memes such as the "Sermon Response Kit" that features popular emojis acknowledge the necessity of moving church into technological forums such as Zoom or other streaming services and tacitly encourage the use of now familiar and common texting practices in a heretofore 
unthinkable religious context. Another meme shows an individual lying in a parking spot, an activity described by the meme as "saving a seat for your friend at the church drive-in service", which transposes a common activity, especially of children, in in-person church services-saving a seat for a friend-to the new circumstance of churches meeting in cars and in parking lots. These memes, along with several of those described above, showcase the adaptability of religious practices to challenging circumstances and how COVID-19 has facilitated creative innovations to make such practices possible. Though many of these memes are tongue-in-cheek and do not depict actual circumstances of people employing these innovations in religious contexts, their use in the real world is not beyond the realm of possibility. Some do, in fact, seem to depict actual behaviors, including one meme that shows a priest giving a socially distanced blessing with a squirt gun. The overall positive framing of these memes is that life continues on, and religious individuals and organizations can creatively adapt to even the most challenging of circumstances.

The positive themes of churches encouraging COVID-19 protocols and innovating creatively due to COVID-19 are similar in how they encourage religious adherents to transcend their circumstances by tying religious belief to practices that can be actively adopted to give the individual some stake in the outcome (Figure 6). Effectively, both themes see COVID-19 as something to be confronted, adapted to, and transcended rather than as something that ought to limit religious expression. Even where the pandemic was represented in terms of "limitations", such as when it prevents in-person gatherings, the larger thematic narratives in these memes exhorted religious groups to see this as opportunity to show religious commitment and love for others. Even though the pandemic is acknowledged as harmful and even just inconvenient, these memes approach the pandemic as simply another historical event to which religion is called to respond and even conquer. Encouraging individuals to practice social distancing and humorously showcasing the ways that people have or could socially distanced has the effect of empowering the individual in their adoption of these practices while celebrating them as an expression of religious faith.

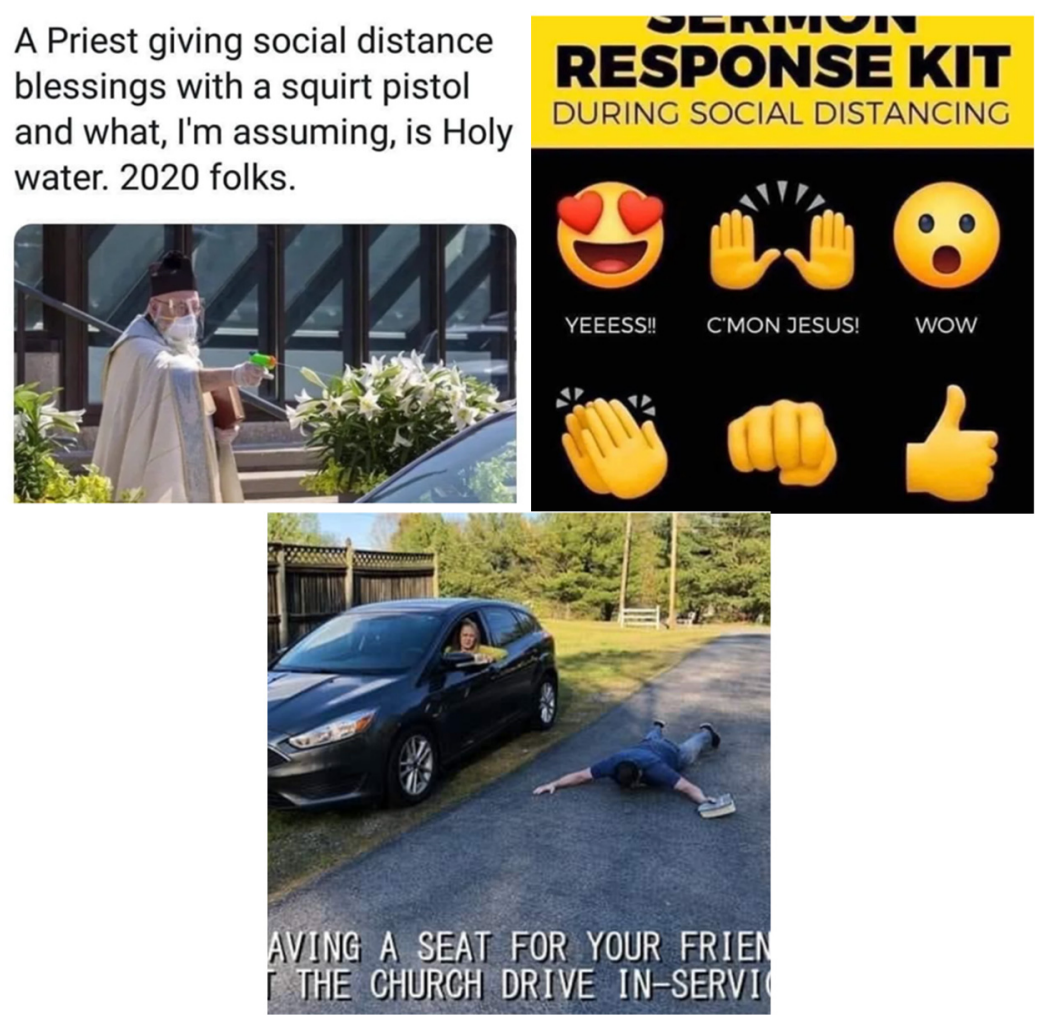

Figure 6. Examples of memes showing playful interpretations of how leaders and church members embrace social-distancing and create alternatives religious and social practices. 


\subsection{Negative Narratives about Religion}

Yet not all representations of religiously motivated responses to the pandemic were positive. Within this sample of memes, two notable critical narratives about religious groups were found: one arguing that most American churches were hypocritical and selfish in their primary response to the pandemic and a more general underlying narrative that implicitly sees religion as stern and problematically unchanging in the face of unprecedented global circumstances.

\subsubsection{American Churches as Hypocritical/Selfish}

Many memes suggest that most churches were more concerned about getting back to face-to-face gathering and in-person worship than about the health and safety consequences those moves might have for congregational members and others in their social circles. As mentioned previously, churches quickly became a flashpoint for arguments about the entanglement of faith and politics as some religious organizations sought exemptions to mandated limits on gatherings or mask-wearing, along with questions about the role of religion in the world in general (Figure 7). For instance, one meme featured the text of a tweet that questioned the way that religious groups were handling the pandemic by tying their behaviors to themes and events from Christian history: "So, in conclusion, the Pope says you can worship God at home just fine and don't need the priest as intercessor in these trying times; and the evangelical protestants have come out against the priesthood of the believer and say church service is necessary to the faith. OK then". Calling out the seeming hypocrisy of both the Roman Catholic Church and Evangelical Protestants, this meme questions the underlying motivations of both the arguments of church history and the contemporary responses of religious groups to the pandemic. Similarly, a meme that characterizes some churches as crying and screaming at the thought of being closed for worship due to government mandates calls such churches out for having American flags in their sanctuaries, suggesting that ties between religion and politics in America are matters of convenience more than conviction.

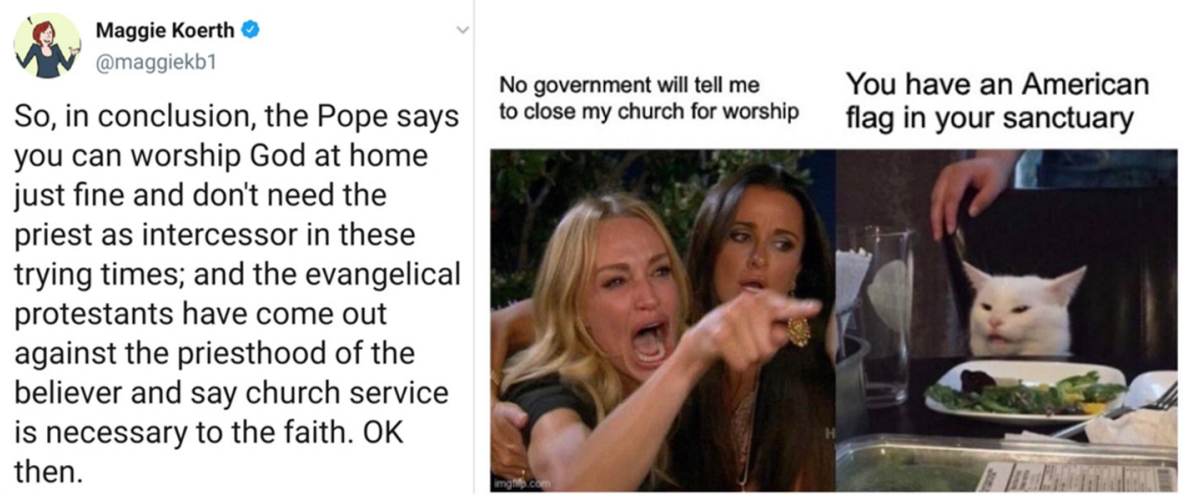

Figure 7. Examples of memes that emphasize church members are against social distancing practices and the contradictions within their justifications for their stance.

\subsubsection{Religion as Unchanging and Resistant}

In some of the memes, there is an underlying narrative tone implying that following COVID-19 safety protocols is actually against the general nature of the modern church (Figure 8). Though many of the memes are structured in such a way that they encouraged following social distancing protocols, and frame doing so as a positive thing that is in step with the character of religious expression, there is also an ironic or sardonic flavor to some of these memes that undercuts the sacrality of religion. For instance, one meme centers on the idea of Catholic nuns being stern and unyielding, depicting a nun holding a ruler with a dour expression her face, captioned "Retired nuns called back to enforce social distancing". Playing on the historical reputation of nuns in Catholic schools as strict, even violent disciplinarians, the meme's playfulness is undermined by the way it foregrounds 
a negative stereotype about religious figures. Another example can be seen in a meme featuring an image depicting Jesus cleansing the temple by chasing the money changers out, pulled from biblical passages such as Matthew 21: 12-17 and John 2: 13-22, with the caption, "Christ reminding people that social distancing to save lives is more important than the economy". While the meme implies a positive valence towards the practices of social distancing, the context of the story and the depiction of Christ is more prominently negative towards religious individuals. In the biblical story of the cleansing of the temple, those that Christ drove out were culturally seen as typically religious individuals; Jesus's action was thus a radical intervention that chastised the traditionally religious. The meme could be interpreted as Christ violently correcting most modern religious adherents who were not practicing social distancing and other public health protocols. Though Jesus is himself depicted as promoting the right behaviors, albeit violently, the meme criticizes the lackadaisical attitude of religion and religious adherents who may not have taken social distancing and other protocols seriously. The critique, then, is that the general nature of the modern church has been to avoid changing their traditions and behavior despite the global pandemic. Even playful, generally positive memes such as those referenced above about adapting traditions such as baptism can be read along these lines: instead of doing everything in their power to combat the spread of COVID-19, churches, and their rush to adapt their rituals to these circumstances, can be seen as selfish and unchanging, ostensibly unwilling to do their whole part to keep people safe from the virus.

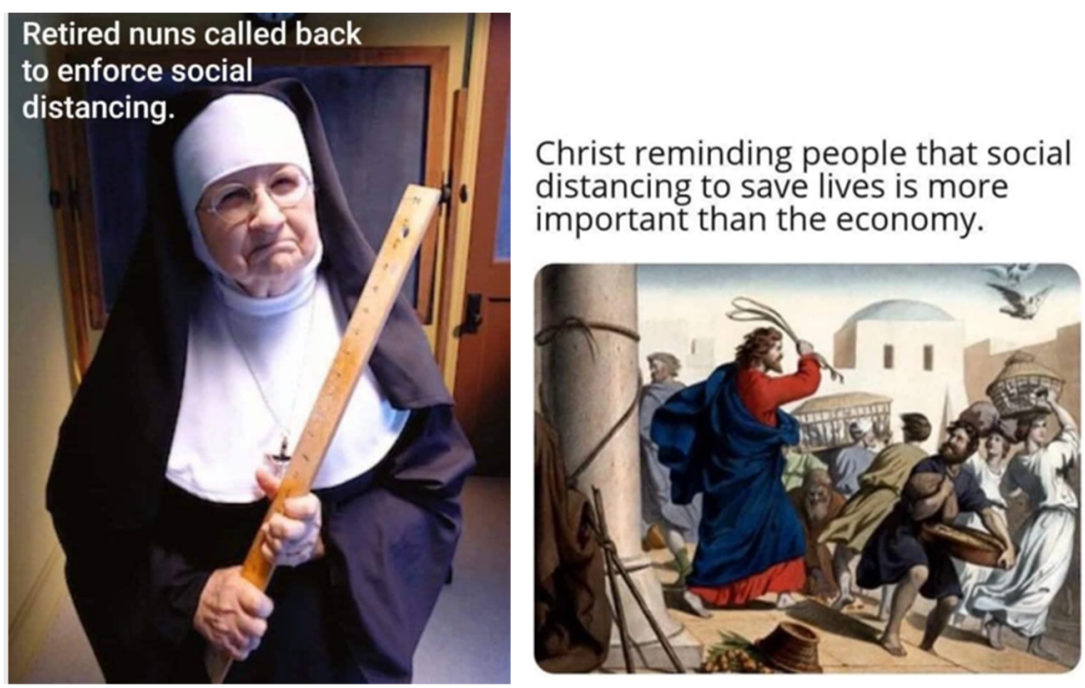

Figure 8. Examples of memes that depicit Christian leaders as unkind or violent in their response to enforcing social distancing.

Thus, even as these memes encourage religious adaptation to public health protocols and often directly promote practices such as social distancing, they can also be seen as characterizing religion in a negative light. Some of these memes assume that religions and religious individuals behave badly or will behave badly considering the restrictions on or changes to their religious practices. Even generally innocuous memes such as those joking about falling asleep during "Zoom church" can be seen as lampooning a stereotypical lack of engagement with Christians in church services. A negative framing can arguably be seen in the existence of many of these memes in the first place. Using memes and memetic humor to encourage adherence to social distancing protocols can be a way of making sense of changed circumstances, but the construction of these memes assumes that some people and populations will need to be convinced to follow those protocols, communicating an implied assumption that people will not follow or will not want to follow those guidelines on their own and that they actually need to be convinced in order to do so. These memes that reference religious figures and seem directed towards a religious population, then, assume that religious individuals will be amongst those that will not want to follow the 
guidelines and so need to be convinced that doing so actually aligns with the religious beliefs they profess.

\section{Conclusions and Implications of Religion-Focused Pandemic Memes}

Our study of religious memes collected on Facebook during the early months of the global coronavirus pandemic point to some intriguing discrepancies in the narrative of religious responses to social distancing guidelines. Religion is depicted in these memes as possessing values that should inherently affirm these health and safety practices. Yet this same collection also supports the assumption that religious groups are unwaveringly wedded to their own traditions and structures, so much so that they will resist anything that requires change or altering their established culture. Important to note is that although the memes selected here emphasize the American Christian context, the implications of their narratives could arguably be extended to memetic framings of religion in general during the pandemic, especially in Western contexts.

Like memes in general, most memes in this study adopted a playful, humorous posture that entertained while nonetheless containing elements of ironic critique. In this instance, these memes used religious figures, imagery, and references to religious practices to encourage adherence to social distancing while subtly critiquing responses to the pandemic by religious organizations and individuals.

The humor used in these memes helped to positively frame the actions of social distancing, mask-wearing, and remote gathering via technologies such as Zoom, and to tie these actions to the proper exercise of religious belief. Though unusual, sometimes inconvenient, and even divisive, the public health and safety practices encouraged by the $\mathrm{CDC}$ and the $\mathrm{WHO}$ were positively positioned in narratives that saw their implementation as the proper response by religious individuals and organizations. Memes in our sample encouraged adherence to such guidelines and seemed to characterize them as another evolution of the stories that religions like to tell about themselves. Wearing a mask, watching church at home, and standing six feet apart was characterized as a beautiful, even generous way to love one's neighbor, a continuation of the kinds of religious messages that Christianity and other world religions preach to their adherents. This narrative framing argues that social distancing ought to be positively embraced by religions and religious individuals.

At the same time, the use of irony to positively frame the actions of social distancing contain a subtle critique of religion itself, namely that religions and religious individuals are oriented more towards cultural practices than they are to the core values of their religious beliefs. Portrayals of adapted religious rituals, of empty churches, and even of stern religious figures from nuns to Jesus himself are all oriented towards introducing a kind of ironic absurdity into the discourse surrounding religious responses to the pandemic. Images of priests and pastors introducing "new" ways to baptize believers are humorous, but also beg the question of how important baptism is at a time of unprecedented global unrest and mortal danger. Such memes paint religion across the world, but especially in America, negatively and as being more concerned with its own traditions and the ostensible necessities of its own cultural or subcultural norms than with the safety of others or with respecting local, state, and even national guidelines.

These memes contribute to the ongoing study of how memes, religion, and digital culture mix and can be used to depict currently popular beliefs and assumptions about religious traditions and groups in contemporary society. We see, as Aguilar et al. (2017) explains, that while most memes emphasized a playful response to religion, critical narratives about religious groups' reactions to social distancing were also present. This shows a notable tension between how religious groups' beliefs align with an ethic of care for the other and the perceived reality that Christian responses actually ran counter to this narrative. COVID-19 upset the normal rhythms of life across the world and, in so doing, created a curious, if unfortunate, laboratory in which some of the fault lines of contemporary culture, media, and individual action could be clearly visible. Our study demonstrates a discernible discrepancy 
in some of the narratives told about Christianity across the early months of the pandemic. Positive framings about the practices of social distancing and their ostensible links to the right religious practice were contrasted with negative portrayals of religion and religious individuals in opposition to those practices. One result of such discrepant narratives is the opening of a discursive space for discussing and addressing the role of religion and religious rituals in media and culture as the world continues to respond to and learn to live with COVID-19. This study indeed opens the door for more study on how internet memes visually and textually represent religion in digital culture, the contested nature of those representations, and how these playful but powerful narratives might inform public perception of religion during times of crisis.

Author Contributions: Authors contributed equally to this paper and both authors have read and agreed to the published version of the manuscript.

Funding: This research received no external funding.

Institutional Review Board Statement: Not applicable.

Informed Consent Statement: Not applicable.

Conflicts of Interest: The authors declare no conflict of interest.

\section{References}

Aguilar, Gabrielle K., Heidi A. Campbell, Mariah Stanley, and Ellen Taylor. 2017. Communicating Mixed Messages About Religion through Internet Memes. Information, Communication \& Society 20: 1458-520.

Al-Rawi, Ahmed, Maliha Siddiqi, Xiaosu Li, Nimisha Vandan, and Karen Grepin. 2021. A thematic analysis of Instagram's gendered memes on COVID-19. Journal of Visual Communication in Medicine, 1-14. [CrossRef] [PubMed]

Bellar, Wendi, Heidi A. Campbell, Kyong J. Cho, Andrea Terry, Ruth Tsuria, Aya Yadlin-Segal, and Jordan Ziemer. 2013. Reading religion in internet memes. Journal of Religion, Media \& Digital Culture 2: 1-39.

Borrough, Benjamin, and Gavin Feller. 2015. Religious memetics. Institutional authority in digital/lived religion. Journal of Communication Inquiry 39: 357-77. [CrossRef]

Campbell, Heidi A. 2020a. The Distanced Church: Reflections on Doing Church Online. Available online: https:/ / oaktrust.library.tam u.edu/handle/1969.1/187891 (accessed on 8 June 2021).

Campbell, Heidi. 2020b. Religion in Quarantine: The Future of Religion in a Post Pandemic World. Available online: https: / / oaktrust.library.tamu.edu/handle/1969.1/188004 (accessed on 8 June 2021).

Campbell, Heidi. 2020c. Social Distancing in a World of Memes. Available online: https://doi.org/10.21423/socialdistancinginaworl dofmemes (accessed on 8 June 2021).

Campbell, Heidi. 2021. Revisiting the Distanced Church. Available online: https://oaktrust.library.tamu.edu/handle/1969.1/193368 (accessed on 8 June 2021).

Campbell, Heidi, Katherine Arrezndo, Katie Dundas, and Cody Wolf. 2018a. The Dissonance of "Civil” Religion in Religious-Political Memetic Discourse During the 2016 Presidential Elections. Social Media + Society 4: 1-15. [CrossRef]

Campbell, Heidi, Lane Joiner, and Samantha Lawrence. 2018b. Responding to the Meme-ing of the Religious Other. Journal of Communication and Religion 14: 27-42.

Church, Scott Haden, and Gavin Feller. 2020. Synecdoche, Aesthetics, and the Sublime Online: Or, What's a Religious Internet Meme? Journal of Media and Religion 19: 12-23. [CrossRef]

Dewi, Rahmi Surya. 2018. Utilization of Internet Memes: Political Social Context and religion in the Governor Election DKI Jakarta 2017. Ushuluddin International Conference (USICON). Available online: http:/ / conference.uin-suka.ac.id/index.php/USICON /article/view/356 (accessed on 14 July 2021).

Duerringer, Christopher. 2016. Who would Jesus bomb? The Republican Jesus meme and the fracturing of ideology. Social Media + Society 2: 1-12. [CrossRef]

Gjelten, Tom. 2020. Things Will Never Be the Same.' How the Pandemic Has Changed Worship. NPR. Available online: https: //www.npr.org/2020/05/20/858918339/things-will-never-be-the-same-how-the-pandemic-has-changed-worship (accessed on 30 June 2021).

Hutchings, Tim. 2013. Confronting religious community through online churches. In Digital Religion: Understanding Religious Practice in New Media Worlds. Edited by Heidi A. Campbell. New York: Routledge, pp. 164-71.

Merkert, Katharina Luise. 2021. Witz und Religionskritik in Internet-Memes. In Religion, Medien und die Corona-Pandemie. Baden-Baden: Nomos Verlagsgesellschaft Mbh \& Co., pp. 77-84. [CrossRef]

Lovett, Ian. 2021. White Evangelicals Rists COVID-19 Vaccine Most among Religious Groups. The Wall Street Journal. Available online: https: / / www.wsj.com/articles/white-evangelicals-resist-COVID-19-vaccine-most-among-religious-groups-11627464 601 (accessed on 27 August 2021). 
Milner, Ryan. 2018. The World Made Meme. Cambridge: MIT Press.

Molina, Alejandra. 2020. John Macarthur Believes the Bible Trumps COVID-19 Public Health Orders. Legal Scholars Say No. Religion News Service. Available online: https:/ / religionnews.com/2020/08/06/john-macarthur-believes-bible-trumps-COVID-19-restri ctions-constitutional-law-experts-say-biblical-duties-dont-trump-u-s-laws / (accessed on 30 June 2021).

Pew Research Center. 2021. More Americans than People in Other Advanced Economies Say COVID-19 Has Strengthened Religious Faith. Available online: https:/ / www.pewforum.org/2021/01/27/more-americans-than-people-in-other-advanced-economi es-say-COVID-19-has-strengthened-religious-faith/ (accessed on 27 January 2021).

Pulos, Rick. 2021. COVID-19 crisis memes, rhetorical arena theory and multimodality. Journal of Science Communicatio 19 : A01. [CrossRef]

Rajan, Benson, and Shreya Venkatraman. 2021. Insta-hate: An exploration of Islamophobia and right-wing nationalism. on Instagram amidst the COVID-19 pandemic in India. Journal of Arab \& Muslim Media Research 14: 71-91. [CrossRef]

Schor, Elana. 2020. Coronavirus gathering bans raise religious freedom questions. AP News. Available online: https://apnews.com / article/virus-outbreak-donald-trump-us-news-ap-top-news-pandemics-c6198ba98ea6d26b128044ea59b9b4da (accessed on 14 July 2021).

Schultze, Quentin. 1991. Televangelism and American Culture: The Business of Popular Religion. Grand Rapids: Baker House Books.

Sebba-Elran, Tsafi. 2021. A pandemic of jokes? The Israeli COVID-19 meme and the construction of a collective response to risk. HUMOR 34: 229-57. [CrossRef]

Shifman, Limor. 2013. Memes in Digital Culture. Cambridge: MIT Press.

Singler, Beth. 2020. The AI Creation Meme: A Case Study of the New Visibility of Religion in Artificial Intelligence Discourse. Religions 11: 253. [CrossRef]

Wiggins, Bradley. 2019. The Discursive Power of Memes in Digital Culture Ideology, Semiotics, and Intertextuality. New York: Routledge.

Yadlin-Segal, Aya. 2015. Communicating Identity through Religious Internet Memes on the 'Tweeting O. thodoxies' Facebook Page. In Digital Judaism: Jewish Negotiations with Digital Media and Technology. Edited by Heidi A. Campbell. New York: Routledge, pp. 109-24.

Yee, Vivian. 2020. In a Pandemic, Religion Can Be a Balm and a Risk. The New York Times. Available online: https: / www.nytimes.co $\mathrm{m} / 2020 / 03 / 22 /$ world/middleeast/coronavirus-religion.html (accessed on 30 June 2021).

Yuko, Elizabeth. 2020. How Religions Are Adapting to Coronavirus. Rolling Stone. Available online: https://www.rollingstone.com/c ulture/culture-features / coronavirus-COVID-19-religion-mosque-synagogue-church-966531/ (accessed on 30 June 2021). 